\title{
"What dO YOU MEAN I CANNOT CONSENT FOR MY Grandmother's Medical Procedure?": Key IsSUES With State Default Surrogate Decision Making LAWS
}

Amber R. Comer, JD, PhD, ${ }^{*}$ Margaret Gaffney, MD, ${ }^{* *}$ Cynthia Stone, DrPH, RN, ${ }^{* * *}$ Alexia Torke, MD, MS ${ }^{* * * *}$

\section{TABLE OF CONTENTS}

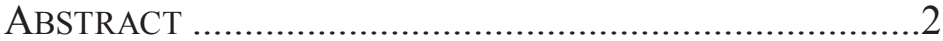

I. INTRODUCTION ....................................................... 3

II. LEGAL AND ETHICAL HISTORY OF SURROGATE DECISION-

MAKING

III. METHODOLOGY …...................................................... 10

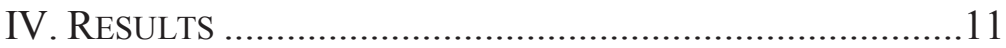

V. DISCUSSION ...........................................................13

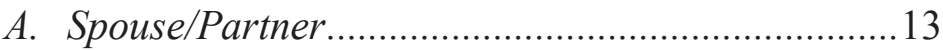

B. Grandparents/Grandchildren ............................... 15

C. Same-Sex Partners .................................................16

D. Adult Relative/Close Friend ...................................17

E. The Unbefriended..................................................18

F. Heierarchy ......................................................... 19

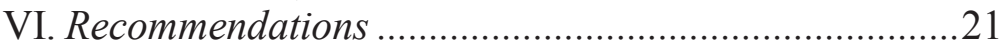

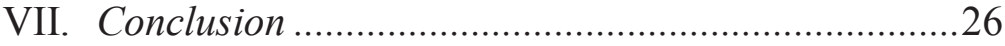

* Indiana University School of Health and Rehabilitation Sciences, 1140 W Michigan Street

Coleman Hall 120 Indianapolis, IN 46202; (317)965-7418; comer@iu.edu;

Financial Support: This work was supported by the Charles Warren Fairbanks Center for Medical Ethics and the Indiana University Center for Aging Research.

${ }^{* *}$ Indiana University School of Medicine

*** Indiana University Richard M. Fairbanks School of Public Health

**** Indiana University Center for Aging Research, Regenstrief Institute, Inc. Charles Warren Fairbanks Center for Medical Ethics, Indiana University Health 
INDIANA HEALTH LAW REVIEW Vol. 14:2

\begin{abstract}
When a patient is unable to make medical decisions, a health care surrogate must be designated to make decisions on the patient's behalf. Studies show that fewer than $20 \%$ of patients have completed health care representative forms to legally designate a surrogate. Without a prior designation, surrogates are determined via state statute. Currently, there is no up-to-date comprehensive evaluation of state surrogate legislation.

A survey of state legislative codes was conducted to determine: 1) whether the state has a default surrogate statute; 2) who is included as an acceptable legal surrogate; and 3) whether there is a hierarchy to determine a final decision-maker. Currently, 36 states have enacted some form of surrogate statute. There is little consistency between states regarding who may serve as a surrogate decisionmaker. The key challenges with state laws include: 1) a narrow list of persons who qualify as allowable legal surrogates; and 2) a lack of a hierarchy to determine a final decision-maker.

The results of this survey show that state surrogate decision making laws have many flaws which could affect patient care. The narrow construction of state laws can leave patients in situations where they either have no qualified surrogate under the law, or where they have multiple surrogates with competing interests who may be unable to reach consensus on the patient's medical care. State laws need to be changed so that they accurately reflect the realities of clinical practice and expanded to allow a broader spectrum of potential surrogates.
\end{abstract}




\section{INTRODUCTION}

An elderly widow with dementia whose only child is deceased has been cared for by her adult granddaughter for the past three years. She is admitted to the hospital for aspiration pneumonia and is currently stable. Her treating physician has determined that she needs a bronchoscopy of her left lower lobe, a procedure that requires informed consent. It is clear that the granddaughter has provided excellent care for her grandmother and wants nothing more than to see her grandmother get better and come home. Would it be appropriate for the granddaughter to consent for her grandmother?

Although allowing the granddaughter to make decisions seems consistent with the principles of medical ethics, the legality of allowing the granddaughter to consent for her grandmother varies from state to state. While it would be ethically defensible to allow the granddaughter to consent for her grandmother, in many states it would be illegal to simply defer to the granddaughter's judgment without a legal surrogate decision making form or guardianship already being in place.

When a patient is incapacitated and unable to make decisions for him or herself, a surrogate decision-maker (also referred to as a proxy decision-maker), must be designated to make decisions about the patient's care in his or her place. ${ }^{1}$ Surrogates are asked to base decisions on what the patient would have wanted, determined by advance directives or to make decisions based on the patient's best interests. ${ }^{2}$ Barring any conflicts of interest, the person who

\footnotetext{
${ }^{1}$ See generally, Allen E. Buchanan \& DAN W. BRock, Deciding FOR OTHERS: THE ETHICS OF SURROGATE DECISION MAKING (1989).

2 Id at 1 ; see generally, BERNARD Lo, RESOLVING ETHICAL Dilemmas: A Guide For Clinicians (5th ed., 2013); Jeffrey T. Berger, Evan G. DeRenzo \& Jack Schwartz, Surrogate Decision Making:
} 
knows the patient the best and is in the best position to understand the patient's desires, needs, and goals is an ethically appropriate surrogate. ${ }^{3}$

Traditionally, immediate family members have filled the role of the surrogate decision-maker because family members are assumed to hold the strongest concern for protecting their loved one's interests. ${ }^{4}$ Additionally, family members are thought to be in the best position to determine patient preferences based on substituted judgment. ${ }^{5}$ Although family members are traditionally thought to be in the best position to serve as a surrogate decision-maker, the concept of a family has changed over the past several

Reconciling Ethical Theory and Clinical Practice, 149 ANNALS OF InTERnAl MEDicine 48, 48 (2008); see also ALlEn E. BuchanAN \& Dan W. Brock, DeCiding for Others: The Ethics of Surrogate DECISION MAKING, 136-139 (1990); see generally, BERNARD LO, Resolving Ethical Dilemmas: A Guide for Clinicians (5th ed., 2013); see also Jeffrey T. Berger, Evan G. DeRenzo \& Jack Schwartz, Surrogate Decision Making: Reconciling Ethical Theory and Clinical Practice, 149 ANNAls of InTERnal Medicine 48, 48 (2008); see also Allen E. Buchanan \& Dan W. Brock, Deciding for Others: The ETHICS OF SURROGATE DECISION MAKING, 136-139 (1990).

${ }^{3}$ BUCHANAN \& BROCK, supra note 1, at 1,3-4; see also American Medical Association. Opinion 8.081-Surrogate Decision Making. In: Code of Medical Ethics of the American Medical Association United States: American Medical Association 2014.

${ }^{4}$ Id. at 1, 3, 4; see also TOM L. BEAUCHAMP \& JAMES F. ChILDRESS, PrinciPles of Biomedical Ethics (Oxford U. Press ed., 7th ed. 2013); see also Javed Butler, Zachary Binnery, Andreas Kalogeropoulos, Melissa Owen, Carolyn Clevenger, Debbie Gunter, et al., Advance Directives Among Hospitalized Patients With Heart Failure, 3 JACC: HEART FAILURE 112 (2015); see also WASH. ST. HOSP. AsS'N, END OF Life CARE MANual: A PROGRAM Guide For Washington Hospitals (2012).

${ }^{5} I d$ at 28. 
decades, necessitating a reevaluation of who should serve as a surrogate decision-maker. ${ }^{6}$

The laws governing health care surrogate decision making vary from state to state. Under state laws, surrogate decision-makers can generally be identified in three ways: 1) a court order, usually in the form of a guardianship; 2) a health care power of attorney document or health care representative form where the patient appoints his or her representative prior to incapacitation; and 3) a default state surrogate decision-maker statute. ${ }^{7}$ The documented presence of a legal health care representative upon patient admission to the hospital is less than $20 \%$ nationally; however, this number is thought to be higher among older adults. ${ }^{8}$ This means that in the hospital, approximately $80 \%$ of patient

6 Jonathan Vespa, JAmie M. Lewis, Rose M. Kreider, AMERICA'S FAMILIES AND LIVING ARRANGEMENTS: 2012, (U.S. Census Bureau ed.; 2013); Charles B. Nam, The Concept of The Family: Demographic and Genealogical Perspectives, 2 SOCIATION TODAY (2004).

7 Rebecca K. Glatzer, Equality at the End: Amending State Surrogacy Statutes to Honor Same-Sex Couples' End-of-Life Decisions, 13 ELDER L.J. 255, 255-82 (2005); Eric D. Correira, Why Rhode Island Needs Default Surrogate Consent Statutes,60 R.I. BAR J11, 11-43 (2012).

${ }^{8}$ Stephanie Gordy \& Eran Klein, Advance directives in the trauma intensive care unit: Do they really matter?, 1 INT'L J. CRITICAL ILLNESS INJ. SCI 132, 132-137 (2011); see also Michele Solloway et al.. A Chart Review of Seven Hundred Eighty-Two Deaths in Hospitals, Nursing Homes, and Hospice/Home Care, 8 J. PALliATIVE Med.; see also 789, 789-96 (2005); Rebecca W. Johnson et al., Reasons for Noncompletion of Advance Directives in a Cardiac Intensive Care Unit, 21 AM. J. OF CRITICAL CARE 311, 311-19 (2012); see also Martin Goodman MT \& Gus Slotman. Effect of advance directives on the management of elderly critically ill patients, 26 CRITICAL CARE MED. 701, 701-04 (1998); see also Maria J. Silveira et al., Advance Directive Completion by Elderly Americans: A Decade of Change, 62 J. AM. GERIATRIC SOC'Y 706, 70610 (2014). 
surrogate decision-makers will be appointed via default state surrogate decision making statutes.

In an effort to encourage patients to engage in advance care planning; the Patient Self Determination Act ("PSDA") was passed at a federal level in 1990. The PSDA requires that all hospitals and health care providers ask each patient upon admission whether he or she would like to complete a health care representative form which usually includes naming a surrogate decision-maker. ${ }^{9}$ In addition to simply asking whether a patient would like to appoint a surrogate decision-maker, hospitals are charged with providing the resources to patients to complete these forms.

Default state surrogate decision making laws are inconsistent and pose many challenges for untraditional families. Many states' default statutes do not permit persons such as grandchildren, unmarried partners, and close friends to make decisions for the patient, unless they have been previously appointed as a health care power of attorney. In these states, potential surrogates must procure a guardianship through the court system in order to make medical decisions for their loved one.

These pitfalls of state surrogate decision making laws have largely been ignored by researchers and policy makers. Although default state laws determine how the majority of surrogate decision-makers are appointed, the overwhelming majority of literature focuses on surrogate decision making via advance directives and guardianships. This paper discusses the legal and ethical history of surrogate decision making, conducts a fifty-state survey of surrogate decision making laws, and discusses the key challenges with these laws affecting patient care including: 1) consistency of state laws; 2) inclusion of persons able to serve as legal surrogates; and 3) presence or absence of a hierarchy among

${ }^{9}$ Federal Patient Self Determination Act of 1990. 42 U.S.C. $\S$ $1395 \mathrm{cc}(\mathrm{a})$ (1990). 
surrogates with no clear final decision-maker. Additionally, this paper recommends that a federal Surrogate Decision Making Act be passed in order to provide standardization among states and provide both a legal and ethical solution to the issues presented.

\section{Legal And Ethical History of SurRogate DECISION-MAKING}

For hundreds of years, medical decisions were largely made by the patient's physician who would determine what treatment was in the patient's best interests, a concept known as paternalism. ${ }^{10}$ The practice of paternalism remained the norm until the mid-1960s when Americans began to place an emphasis on autonomy-the right of patients to make their own medical decisions. ${ }^{11}$ In 1967, the concept of autonomy was extended to patients who were medically incapacitated when Luis Kutner, a human-rights lawyer, published a paper that described the concept of an advance directive. ${ }^{12}$ In 1976, In re Quinlan was the first case to grant the legal right to refuse life support to a patient who was incapacitated. In re Quinlan, the court allowed the parents of a young women in a persistent vegetative state to act on her behalf and remove

${ }^{10}$ J.J. Chin, Doctor-patient relationship: from medical paternalism to enhanced autonomy, 43 SING. MED. J. 152, 152-55 (2002); see also Howard Mayonga, et al., From informed consent to shared decisionmaking, 104 S. AFR. MED. J. 561, 561-62 (2014); see also Gary B. Weiss, Paternalism modernised. 11 J. Med Ethics 4 184, 184-87 (1985).

${ }^{11}$ BuCHANAN \& BROCK, supra note 1, at 27-29; see also Rae Dong. Paternalism in Medical Decision Making. Durham, North Carolina: DUKE UNIV. (2011) [https://perma.cc/T7J5-PSF8].

${ }^{12}$ Henry R. Glick, The Right-to-Die: State Policymaking and the Elderly, 5 J. OF AGING StUdies 283, 283-307 (1991); Charles P. Sabatino, The Evolution of Health Care Advance Planning Law and Policy, 88 The Milbank Q., 211, 212 (2010). 
her from life support. ${ }^{13}$ The parents were the presumed decision-makers because it was assumed that the immediate family member at the incapacitated patient's bedside was the ethically appropriate person to make medical decisions for the patient. ${ }^{14}$ Additionally, In re Quinlan, the New Jersey Supreme Court determined that the right of the next of kin to assume guardianship of an incompetent person "has roots deep in common law." 15 The court further held that the rights of guardians to make decisions for incapacitated patients fell under the constitutional right of privacy. ${ }^{16}$ In summation, the court found that Quinlan's parents were the appropriate guardian for Quinlan and their medical decisions were private and should be honored. ${ }^{17}$

The Quinlan case led to change surrounding surrogate decision making laws in the United States. Later that year, California adopted the first living will statute. ${ }^{18}$ Over the next decade, the use of living wills became extremely popular, and by the end of 1986, forty-one states had adopted living will statutes similar to California. ${ }^{19}$

The idea of using a "durable" power of attorney as a tool for appointing a health care decision-maker was introduced by the President's Commission for the Study of Ethical Problems in Medicine and Biomedical and Behavioral Research in $1983 .{ }^{20}$ From this idea in 1985 , Idaho passed the first state statute determining who would be able to act on behalf of incapacitated patients, as a sort of surrogate

\footnotetext{
${ }^{13}$ In re Quinlan, 355 A.2d 647, 664 (N.J.1976).

${ }^{14}$ BUCHANAN \& BROCK, supra note 1, at 1,3-4, 42, 53.

${ }^{15} \mathrm{Id}$. at 53.

${ }^{16}$ In re Quinlan, 355 A.2d 647, 663 (N.J.1976).

${ }^{17}$ Lo, supra note 2, at 170.

18 Sabatino, supra note 12, at 213.

${ }^{19}$ Glick, supra note 12, at 284; see also Sabatino, supra note 12, at

${ }^{20} \mathrm{Id}$.
} 214. 
decision maker over medical decisions. ${ }^{21}$ By 1989 , fifteen states and Washington, D.C. had passed surrogate decisionmaking statutes. ${ }^{22}$

In Cruzan vs. Director, Missouri Department of Health in 1990, the United States Supreme Court upheld the legal standard that incapacitated persons retain autonomous decision-making through a surrogate. ${ }^{23}$ The Court set the standard that a patient's surrogate was able to refuse lifeprolonging medical treatment for the patient if "clear and convincing evidence" exists that the surrogate was conforming to the patient's wishes. ${ }^{24}$ The Cruzan case was the first case heard by the United States Supreme Court to address the concept of patients retaining autonomy even after medical incapacitation. This case led to the adoption of the Patient Self-Determination Act ("PSDA") in 1990, which requires hospitals to ask patients upon admission if they have a health care representative, and if not, whether they would like help naming one. ${ }^{25}$

As a result of the Cruzan case and the PSDA, the Uniform Law Commission published the Uniform HealthCare Decisions Act ("UHCDA") in 1993. ${ }^{26}$ The UHCDA outlines a list of appropriate surrogates in the event that a

${ }^{21}$ Robert M. Portman, Surrogate Decision-Making Legislation: The Next Frontier in Life-Sustaining Treatment Policy, 24 J. Health \& HosP. L. 311 (1991); see also IDAHO CODE § 39-5306 1985).

${ }^{22}$ BUCHANAN \& BROCK, supra note 1 , at 47.

${ }^{23}$ Cruzan v. Dir., Mo. Dep't of Health, 497 U.S. 261, 262-63, 284 (1990).

${ }^{24} I d$. at $284-85$.

${ }^{25}$ Patient Self-Determination Act of 1990, Pub. L. No. 101-508, 104 Stat. 1388 (1990) (codified as 42 U.S.C. $1395 \operatorname{ccc}(\mathrm{f})(1)(\mathrm{a})$, $1395 \operatorname{ccc}(f)(2)(a)(1995))$.

${ }^{26}$ Uniform Health-Care Decisions Act (1993) (The Uniform Law Commission approved the UHCDA at their National Conference of Commissioners on Uniform State Laws in July and August of 1993; see Brief for Vacco et al. as Amici Curiae Supporting Reversal of Judgments, 1996 WL 656290). 
patient becomes incapacitated without an advance directive. ${ }^{27}$ Contrary to the first surrogate decision-making customs, the UHCDA expanded qualified decision-makers to persons beyond just the patient's family by including a hierarchy of potential alternative surrogates. ${ }^{28}$ The concept of appointing a legal surrogate decision-maker for incapacitated patients, who do not have an advance directive, became mainstream, and by 2002, thirty-five states and Washington, D.C. had adopted a surrogate decision-making law either through legislation or case law. ${ }^{29}$

State surrogate statutes, designating who can serve as a legally authorized surrogate, are a relatively recent concept that have been developed piecemeal throughout the country. Although the laws are not consistent, statutes are credited as one solution for resolving ethical problems with surrogate medical decision-making. ${ }^{30}$ Currently, there is no up-to-date, comprehensive evaluation of state surrogate decision making legislation. In order to determine the current challenges with these laws that affect patient care, a fiftystate review of surrogate decision-making statutes was conducted.

\section{METHODOLOGY}

In 2014, an evaluation of state surrogate decisionmaking statutes was conducted in order to determine variability among state laws. Each state's legislative code

${ }^{27}$ Uniform Health-Care Decisions Act of $1993 \S 5$, U.L.A. Health Care Dec. $\S 5$ (1993).

${ }^{28} I d$.

${ }^{29}$ Andrew T. Wampler, To Be or Not to Be in Tennessee: Deciding Surrogate Issues, 34 U. MEM. L. REV. 333, 378 (2004).

30 NAT'L Bioethics AdVisory COMM'N, RESEARCH INVOLVING PERSONS WITH MENTAL DisOrders That MAY AFFECT

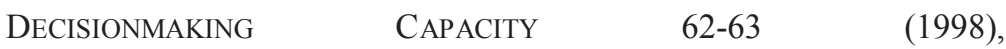
https://scholarworks.iupui.edu/handle/1805/21 [https://perma.cc/2VDA-JPQJ]. 
was reviewed for the following information as it pertains to adult patients: 1) whether the state has a default surrogate law; 2) the code section in which the default state surrogate decision making statute is located; 3 ) the most current year in which that statute was either passed or amended; and 4) who is included as an acceptable legal surrogate under the statute. The full details of this review are located in Appendix 1.

\section{RESULtS}

Currently, forty states have enacted some form of a surrogate decision-making statute that includes: a scheme for appointing a decision-maker for incapacitated adult patients without a court appointed guardian, designated health care representative, or health care power of attorney. ${ }^{31}$ Of the forty states that have enacted these default surrogate statutes, there are only two consistent, allowable surrogates under all state laws: spouses and adult children of the patient. In forty states, parents are specifically named as an allowable surrogate, and in thirty-six states, adult siblings of the patient are specifically named as allowable surrogates. Thirty-two of the forty states with surrogate decision-making laws have included a hierarchy of decision-makers. It is important to note that most states with hierarchies have written their laws so that the hierarchy only takes effect when two or more surrogates, on the same hierarchy tier, cannot reach a consensus on the patient's care.

${ }^{31}$ See infra Table 1. A full review of state surrogate decision making statutes is located in Appendix 1. See infra Appendix 1. 
Table 1. Allowable Surrogate Decision-makers Under State Laws

\begin{tabular}{lc}
\hline Potential Surrogate & $\begin{array}{c}\text { Number of States Which } \\
\text { Allow this Surrogate }\end{array}$ \\
\hline Spouse & 40 \\
Adult Child & 39 \\
Parent & 40 \\
Adult Sibling & 36 \\
Close Friend & 25 \\
Other Adult Relative & 18 \\
Grandchild & 16 \\
Grandparent & 10 \\
Unmarried Partner & 6 \\
Aunt or Uncle & 5 \\
Physician/ Facility & 4 \\
Representative & 2 \\
Cousin & 4 \\
Domestic Partner & \\
\hline
\end{tabular}

It is important to note that under the majority of these surrogate decision making laws, same-sex partners, domestic partners, and unmarried common-law partners did not qualify as spouses at the time of this survey. As of October 2016, only seven states had directly addressed these issues in their statutes: the states of Washington and New York, which specifically allowed domestic partners to serve as surrogates, and Alaska, Arizona, Maine, New Mexico, and Oregon, which specifically allowed unmarried partners to serve as surrogates. Although same-sex couples qualifying as surrogate decision-makers was an issue at the time of this survey, a recent United States Supreme Court 
decision, legalizing same sex marriage in the United States, allows legally married partners to serve as surrogates, alleviating some of the surrogate issues same-sex couples face. $^{32}$

Only one state, North Dakota, has codified the right of a step-parent to make decisions on behalf of a step-child. Additionally, only eight states, Georgia, Louisiana, New Mexico, North Dakota, South Carolina, South Dakota, Utah, and Wyoming, allow grandparents to consent for grandchildren. ${ }^{33}$ Furthermore, only sixteen state statutes explicitly permit grandchildren to consent to care on behalf of their grandparents. Five states allow aunts and uncles, and only one state, South Dakota, allows cousins. ${ }^{34}$

When no family member is available, twenty-five states allow close friends to make surrogate decisions; two states, Indiana and Texas, allow religious superiors of patients in avowed religious orders to make decisions; and three states, Arkansas, Idaho, and Pennsylvania, allow a physician with the help of an ethics committee to make decisions for incapacitated patients.

\section{Discussion}

\section{A. Spouse/Partner}

This review shows that the most common surrogate decision-makers in state statutes are spouses and adult children. In all forty states with surrogate decision-making laws, the spouse is listed as an appropriate surrogate decision-maker. Although the practice of utilizing the spouse as the surrogate decision-maker is ethically appropriate, the data shows that the modern cultural norm has dramatically

\footnotetext{
${ }^{32}$ See Obergefell v. Hodges, 135 S. Ct. 2584 (2015).

${ }^{33}$ See infra Table 2.1.

${ }^{34}$ See infra Appendix 1 for complete list of included states.
} 
shifted and many persons are no longer legally marrying the person that they choose as their long-term partner or "spouse." "35 For example, only 1,560,000 persons in the 1980 U.S. Census indicated that they lived unmarried with their partner; ${ }^{36}$ however, by 2008 , that number had increased to 6.2 million persons. ${ }^{37}$

The drastic shift in unmarried partners, who choose to live together, poses an issue when a surrogate decisionmaker is needed. Only six state laws directly allow partners in this situation to make decisions for one another. In twentyfive states, persons living in this situation would qualify as a decision-maker under the "close friend" provision; however, other people who may not be as close to the patient, such as distant relatives, would rank higher on the priority list of decision-makers.

In the thirty-two states with surrogate statutes that do not expressly permit unmarried, long-term partners to serve as

\footnotetext{
35 U.S. Census Bureau, Marital Status and Living ARRANGEMENTS: $\quad$ MARCH $\quad 1980 \quad 4-5 \quad$ (1980), https://www.census.gov/prod/1/pop/p20-365.pdf [https://perma.cc/2JF5-ZGV2]; see also JASON FIELDS \& LYNNE M. Casper, U.S. Census Bureau, America's Families and Living ARRANGEMENTS: POPULATION CHARACTERISTICS 2 (2000), https://www.census.gov/prod/2001pubs/p20-537.pdf

[https://perma.cc/4HZH-D2TU]; see also U.S. CENSUS BUREAU, Unmarried and Single Americans WeEK: SePt. 21-27, 2014, 2 (2014), https://www.census.gov/content/dam/Census/newsroom/factsfor-features/2014/cb14ff-21_unmarried.pdf [https://perma.cc/H4FG9V9V].

36 U.S. Census Bureau, Marital Status and Living ARRANGEMENTS: $\quad$ MARCH $1980 \quad 4-5 \quad$ (1980), https://play.google.com/books/reader?id=RggcDfBlBEUC\&printsec $=$ fr ontcover\&output=reader\&hl=en\&pg=GBS.PP1 [https://perma.cc/V9LK-JFT8].

37 The Decline of Marriage and Rise of New Families, Pew RESEARCH CENTER: SOCIAL \& DEMOGRAPHIC TRENDS (Nov. 18, 2010), http://www.pewsocialtrends.org/2010/11/18/vi-new-family-types/ [https://perma.cc/DF6E-A48A].
} 
decision-makers, a long-term partner would not be able to serve as the patient's surrogate without first pursuing and obtaining legal guardianship through the court system. For example, in Idaho, a state that does not recognize common law marriage, an adult relative, not within the patient's immediate family, such as an uncle, would qualify to serve as a surrogate before a long-term unmarried partner of twenty years. ${ }^{38}$

\section{B. Grandparents/Grandchildren}

Only sixteen states explicitly authorize adult grandchildren to consent for a grandparent, and only eight states allow grandparents to consent for their grandchildren without a court established guardianship. Since surrogate decision-maker laws were first adopted, the number of grandparents, who report being the primary caregiver of their grandchild's basic needs, has increased from only $3 \%$ of grandparents in $1970^{39}$ to $7 \%(2,700,000)$ in $2010 .{ }^{40}$ Additionally, in 2009, 5,300,000 grandchildren were the primary caregiver for their grandparent. ${ }^{41}$

${ }^{38}$ IDAHO CODE $§ 39-4504$ (2016).

39 Ken Bryson \& LynNe M. CASper, U.S. Census Bureau, CORESIDENT GRANDPARENTS AND GRANDCHILDREN 1 (1999), https://www.census.gov/prod/99pubs/p23-198.pdf

[https://perma.cc/2CBB-QMAL].

40 U.S. Census Bureau, Grandparents Day 2012: SePt. 9, 1 (2012),

https://www.census.gov/newsroom/releases/archives/facts_for_features _special_editions/cb12-ff17.html [https://perma.cc/J764-5R7M]; see also Bert Hayslip \& Patricia L. Kaminski, Grandparents Raising Their Grandchildren: A Review of the Literature and Suggestions for Practice, $\begin{array}{llrl}\text { THE GERONTOLOGIST } & 262, & 262 & \text { (2005), }\end{array}$ https://academic.oup.com/gerontologist/article/815984/Grandparents [https://perma.cc/ER8W-6NCP].

${ }^{41}$ Cynthia Ramnarace, The Surprising Caregiver: Your Grandchild, AARP

(Aug.

15 , 2011), 
Although very few states directly address the issue of grandparents and grandchildren consenting for one another, eighteen states allow an adult relative outside of the immediate family to serve as the surrogate decision-maker, and twenty-five states allow close friends. Even though grandparents and grandchildren qualify under "adult relative" or "close friend" provisions in some states, the majority of states still have no way of addressing this relationship under the law. Additionally, both grandparents and grandchildren face the same hurdles as unmarried spouses under hierarchy rules when there is more than one decision-maker available.

\section{Same-Sex Partners}

One of the most dynamic and rapidly evolving groups of potential surrogate decision-makers is same-sex partners. In 1980, only 9980 persons reported living unmarried with a same sex partner; however, by 2010 that number had increased to over half a million persons $(565,000) .{ }^{42}$ In 2014 , the United States Supreme Court declined to hear cases on certiorari regarding state constitutional bans on same-sex marriage. ${ }^{43}$ As a result, the in-place state Supreme Court and federal court decisions remained good law-meaning, that same-sex marriage was legal in only thirty-seven states in

http://www.aarp.org/relationships/caregiving/info-08-2011/grandchildas-caregiver.html [https://perma.cc/V9L5-LGG8] (citing NAT'L ALL. FOR CAREGIVING \& AARP, CAREGIVING IN THE U.S. 200918 (2009), http://www.caregiving.org/data/Caregiving_in_the_US_2009_full_repo rt.pdf [https://perma.cc/2EBQ-9Z2K]).

42 BuCHANAN \& BROCK, supra note 1, at 17, 58-59.

43 Amy Howe, Today's Orders: Same-Sex Marriage Petitions Denied, SCOTUSBlog (Oct. 6, 2014, 10:41 AM), http://www.scotusblog.com/2014/10/todays-orders-same-sex-marriagepetitins-denied/ [https://perma.cc/RE5E-W97J]. 
2014. ${ }^{44}$ In 2015, the United States Supreme Court declared same-sex marriage to be a constitutionally protected right in all states in Obergefell v. Hodges. ${ }^{45}$ Due to the recent Supreme Court Decision in Obergefell v. Hodges, under all state surrogate decision-making laws, same-sex spouses now qualify as a permissible surrogate. ${ }^{46}$

Prior to the recent decision, same-sex partners were only prioritized as surrogate decision-makers in the five states that allowed unmarried partners to serve as surrogates or fell to the bottom of the hierarchy in the twenty-five states that allowed "close friends." Although the issue of same-sex partners serving as surrogate decision-makers, absent a health care representative form, health care power of attorney, or court appointed guardianship, was a problem in the past, the recent Supreme Court decision has settled this issue for same sex couples who choose to marry and extended the same rights that married heterosexual couples hold.

\section{Adult Relative/Close Friend}

Another instance of the shortcomings of state surrogate decision-making laws is evidenced by the failure to account for patients who do not have immediate biological family members. Only twenty-five states have laws which allow for an unrelated person to be a designated decision-maker in the context of a health care delivery setting, rather than to be appointed through the courts to serve as a surrogate in the event that the patient does not have a family member who is able to serve. This category of persons is important for two reasons: 1) it allows a person to serve as a surrogate who is

${ }^{44}$ Same-Sex Marriage Laws, NAT'L CONF. St. Legislatures (June 26, 2015), http://www.ncsl.org/research/human-services/same-sexmarriage-laws.aspx [https://perma.cc/49B7-MZE5].

${ }^{45}$ Obergefell v. Hodges, 135 S. Ct. 2584 (2015).

${ }^{46}$ Obergefell v. Hodges, 135 S. Ct. 2584 (2015). 
not directly related to the patient; and 2) it allows a person to serve as a surrogate who would otherwise be disqualified due to nuances in the law, such as a failure to recognize common law, same-sex marriage, or adult relative outside of the immediate family.

It is both important and ethically appropriate to include close friends on the list of potential surrogate decisionmakers because in many instances, they may be the person who is closest to the patient and understands that patient's values. In states such as Illinois and Pennsylvania, which allow close friends to serve as surrogates, close friends are only able to serve in instances where patients do not have family members who are willing and able to fill the role of health care proxy. ${ }^{47}$ Allowing close friends is important because it alleviates the need to pursue a guardianship through the court in instances where there is an ethically qualified individual willing to serve as the surrogate.

\section{E. The Unbefriended}

There is a significant population of patients that has neither an identifiable family member nor friend to serve as a surrogate. As many as $16 \%$ of patients who die in intensive care units fall into this category of the "unbefriended." 48 In many states, the inclusion of a broad array of available surrogates has prevented many patients from becoming "unbefriended"; however, a large number of states, including Indiana, Alabama, Arkansas, and Kentucky, have health care surrogacy laws which do not authorize close

47 The Illinois State medical Society, A Physician's Guide to Advance Directives: Health Care Surrogates, (last visited May 5, 2017), https://www.isms.org/uploadedFiles/Main_Site/Content/Resources/Me mber_Resources/advance_directives/HealthcareSurrogates.pdf [https://perma.cc/77BZ-557R].

${ }^{48}$ Barry D. Weiss, et al., Medical Decision-Making for Older Adults without Family, 60:11 J. OF THE AM. GERIATRICS SOC'Y 2144 (2012). 
friends or persons outside of the patient's family to serve as surrogates unless formally appointed via a health care representative form. The effect of these narrowly construed laws is that patients essentially become "unbefriended" due to the law and not due to the inability to identify a reasonable decision-maker. State laws need to include ethically appropriate surrogates outside of the patient's family in order to avoid the patient becoming "unbefriended" thus requiring a guardianship.

Although allowing a broad scope of legal decisionmakers will alleviate many situations where patients are deemed "unbefriended," there will still be times when a patient does not have anyone who is able or willing to act as the patient's surrogate. In situations where there is no ethically or legally appropriate surrogate, three states, Arkansas, Idaho, and Pennsylvania have added provisions in their surrogate decision making laws which alleviate the need for a court appointed guardian. These states avoid the need for a court appointed guardianship by allowing physicians to work with hospital ethics committees to make medical decisions for patients.

\section{F. Hierarchy}

A hierarchy of decision-makers is necessary when families cannot come to a consensus on the patient's care. ${ }^{49}$ In states without a hierarchy, families who cannot reach a consensus about the patient's care are left without a legally recognized mechanism for resolving disagreements. ${ }^{50}$ In states with a hierarchy, decision-makers are ranked so that one person may make a final decision about the patient's care without the necessity of court intervention in the event

\footnotetext{
${ }^{49}$ BUCHANAN \& BROCK, supra note 1.

${ }^{50} \mathrm{Id}$.
} 
that the family cannot reach a consensus. ${ }^{51}$ A hierarchy does not mean that families should not or cannot collaborate to make decisions on behalf of the patient. Nor does the presence of a hierarchy mean that someone higher on the surrogate list cannot step aside and allow someone of lower rank to guide decision making.

The hierarchy allows a mechanism for resolving conflicts when patient's families cannot reach a consensus. ${ }^{52}$ If this occurs, there is a process to efficiently identify a default decision-maker who can act in the patient's best interests without involving the court system in an already delicate and difficult situation. ${ }^{53}$ In addition to offering clarity, health care providers reasonably relying upon decisions made on behalf of an incapacitated patient by a surrogate decision-maker identified under the state law are protected against certain types of civil lawsuits and complaints filed with licensing boards. ${ }^{54}$

Although a hierarchy offers protection from judicial proceedings in the event that surrogates disagree, a hierarchy can have the negative effect of placing an ethically appropriate surrogate decision-maker in a position where he or she can be overruled legally by someone who is not as close to the patient. Several examples of this issue can be found in states that do not specifically allow long-term unmarried partners, same-sex partners, and grandparents/ grandchildren and others who would commonly be available, to serve as surrogates, such as Indiana. Although

${ }^{51}$ Guidance For HealthCare Ethics Committees 65 (D. Micah Hester \& Toby Schonfeld, eds., Cambridge University Press) (2012).

${ }^{52}$ Forrest Lang \& Timothy Quill, Making Decisions with Families at the End of Life, 70(4) AM. FAMILY PHYSICIAN 719 (2004).

${ }^{53}$ Shana Wynn, Decisions by Surrogates: An Overview of Surrogate Consent Laws in the United States, 36:1 BIFOCAL: J. OF THE AM. BAR. Assoc. COMM'N ON LAW AND AgING 10 (2014).

${ }^{54}$ IND. CODE $§ 16-36-1-5$ (2008); see also IND. CODE $§ ~ 29-3-3-4$ (2008). 
this potential issue is further complicated by complex family situations, it can potentially be mitigated by adopting a comprehensive statute which specifically names persons who can serve as surrogates. ${ }^{55}$

\section{RECOMMENDATIONS}

In order to ensure that an incapacitated patient's autonomy is protected and that his or her interests are preserved, it is recommend that the state statutes expand the list of potential surrogates to include individuals who are often in the position of caregiver and decision-maker for incapacitated patient and specify who may serve as an allowable surrogate decision-maker and in what order of priority each surrogate holds final decision making capacity. As shown in the section above, many state laws do not allow unmarried partners, same-sex partners, grandparents, grandchildren, or extended family members to make decisions for patients when they are incapacitated, even though they may be the most appropriate surrogates based on knowledge of patient preferences and interests. Thus, many situations exist in which patients do not have an available family member as defined under the state law to make medical decisions. The narrow construction of what constitutes a family member under these state laws has the potential to legally disqualify ethically appropriate surrogates, creating unnecessary stress and tension during times that are already daunting and difficult for both the patient and his or her family. ${ }^{56}$

Another challenging issue which results when a legal surrogate is not available or a final decision-maker is not appointed is the requirement of court intervention to

${ }^{55}$ Erin S. DeMartino et al., Who Decides When a Patient Can't? Statues on Alternative Decision Makers, 376:15 New ENGLAND J. OF MED. 1478 (2017).

${ }^{56}$ BUCHANAN \& BROCK, supra note 1, at 47. 
establish guardianship. When an available patient surrogate decision-maker is not included in the state statutory list, the potential surrogate must pursue a guardianship through the court system in order to make medical decisions for the patient. Pursuing a guardianship can be expensive and time consuming, and may lead to a delay in patient care as decisions are delayed until the surrogate is officially appointed by the court. ${ }^{57}$ Allowing close friends to serve as guardians may eliminate the need for a public guardian in some cases..$^{58}$

It has been proposed that more education is necessary so that people will appoint their desired surrogate decisionmaker in advance; however, educational incentives have already been attempted and have historically failed to yield a drastic change, although this issue is somewhat improving among older adults. ${ }^{59}$ Although there are educational incentives and national policies (such as those offered through the PSDA) presenting patients with the resources and opportunity to complete a health care power of attorney, nearly all incapacitated patients will derive their surrogate

${ }^{57}$ IND. CODE § 29-3-3-4(a) (2016); see also BUCHANAN \& BROCK, supra note 1, at 20, 55; see also Robin Fretwell Wilson, Hospital Ethics Committees as the Forum of Last Resort: An Idea Whose Time Has Not Come, 76 N.C. L. REV. 353, 353-406 (2014); see also JESSICA W. BERG ET AL., INFORMED CONSENT: LEGAL THEORY AND CliniCAL PRACTICE (Oxford University Press, 2d Ed. 2001).

58 Report to THE Supreme Court of WASHington AND THE BOARD OF JUDiCIAL ADMINISTRATION, A PROPOSAL FOR A COMPREHENSIVE StATUTORY FrameWORK TO PROVIDE DECISIONMAKING ASSISTANCE TO PERSONS WITH DiminishED DECISION-MAKING CAPABILITY, (2009).

59 See Dee Leahman, Why the Patient Self-Determination Act Has Failed, 65 N.C. MED. J. 249, 250 (2004); see also Jeffrey L. Yates \& Henry R. Glick, The Failed Patient Self-Determination Act and Policy Alternatives for the Right to Die, 9 J. AgING \& Soc. POL'Y, 29, 29-50 (1997). 
decision-maker from state laws. ${ }^{60}$ In many states, the surrogate decision-making statute is premised on outdated presumptions regarding who qualifies as a family member, creating an ethical quandary for physicians-should physicians allow the ethically appropriate or the legally appropriate surrogate to make decisions for the incapacitated patient. Given the importance of these statutes, state laws should be amended to best represent the modern American family in order to protect patient autonomy and serve the best interests of the patient.

In order to achieve standardization of surrogates throughout states, the PSDA should be amended to include a federal surrogate decision law. A federal law would allow consistency for patients and physicians throughout the United States and help alleviate the numerous pitfalls of surrogate decision-making that many state laws currently create. The proposed federal law should be broad enough that it protects patient's autonomy and does what is in the best interest of the patient. This can be accomplished by allowing ethically appropriate surrogates, who may not be related to the patient, to serve as the surrogate in the event that a legally appropriate family member is not present. Additionally, the federal law should specify one final decision-maker in the event that there are multiple surrogates who cannot come to a consensus.

The following proposed model rule from the state of Pennsylvania accomplishes the aforementioned tasks. The proposed rule reads as follows:
A) If an individual incapable of consenting to their health care has not appointed a legal health care representative or if said appointed

${ }^{60}$ Amber Comer et al., Physician Understanding and Application of Surrogate Decision-Making Laws in Clinical Practice, AJOB EMPIRICAL BIOETHICS 1 (2016). 
health care representative is not reasonably available or declines to act, consent to health care may be given by the following in the following order of priority:

1) By a judicially appointed guardian of the person; or

2) Spouse;

3) An adult who has lived with the patient and exhibited the special care and concern for the patient similar to a spouse;

3) Adult child;

4) Parent;

5) Sibling;

6) An adult who has exhibited special care and concern for the patient and has knowledge of the patient's preferences and values.

B) If more than one member of a class assumes authority to act as surrogate and they do not agree on a healthcare decision and the supervising healthcare provider is so informed, the supervising healthcare provider shall comply with the decision of a majority of the members of that class who have communicated their views to the provider. If the class is evenly divided concerning the healthcare decision and the supervising health care provider is so informed, then the 
healthcare provider will proceed to do what is in the best interest of the patient.

C) In the absence of any legal guardian or other representative described in subdivision (A) or if a guardian or other representative is not reasonably available or declines to act, or the existence of the guardian or other representative is unknown to the health care provider, the designated physician may make healthcare decisions for the patient after the designated physician:

1) Consults with and obtains the recommendations of an institution's ethics officers; or

2) Obtains concurrence from a second physician who is: (i) not directly involved in the patient's health care; (ii) does not serve in a capacity of decision making, influence, over responsibility over the designated physician; and (iii) does not serve in a capacity under the authority of the designated physician's decisionmaking, influence, or responsibility. ${ }^{61}$

While the proposed model legislation cannot anticipate all potential problems with surrogates, such as instances where a patient may be estranged from their family and would rather have a friend make their decisions, it is a comprehensive act that would alleviate the majority of

\footnotetext{
6155 PA. CODE $§ 6000.1013$ (2017).
} 
current pitfalls. Specifically, this law gives priority to unmarried long term partners who may have functioned in the role of spouse without a legal marriage. Additionally, the language of this legislation is general enough that grandchildren or other relatives as well as close friends who have served in a caregiving role will have legal authority to make decisions. Additionally, this law provides a hierarchy to be provide a legal mechanism for resolving disputes. Given the inconstancy and pitfalls of state laws, a federal law, which mirrors the proposed rule, would be the best solution to the current Surrogate Decision Making issues the United States faces.

\section{CONCLUSION}

This review of state surrogate decision-making laws reveals that there is very little consistency among states regarding who may serve as a surrogate decision-maker. Due to the variability of surrogate decision making laws among states, it is easy to imagine a situation where a patient would not have an ethically appropriate surrogate who is recognized under current state laws. It is imperative that state laws be amended so that they are applicable to clinical practice. In order to best address the current pitfalls of surrogate decision making laws, an amendment to the federal PSDA should be passed, which mirrors the rule proposed in this article, in order to optimize the quality of surrogate decisions and provide consistency among states. 
Table 2. Health Care Consent Laws Throughout the United States

\begin{tabular}{|c|c|c|c|c|c|c|c|c|c|c|c|c|c|c|c|c|c|c|c|c|}
\hline an & $\mathrm{cas}$ & 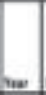 & sule & t: & tenas & \begin{tabular}{|l} 
Doventar: \\
netrer
\end{tabular} & $\begin{array}{l}\text { unente } \\
\text { intwe }\end{array}$ & $\begin{array}{l}\text { wa.t } \\
\text { oint }\end{array}$ & Dons & $\begin{array}{l}\text { Nean } \\
\text { Soin. }\end{array}$ & 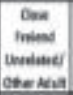 & comen & 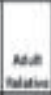 & aneters & Arovinens & 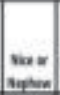 & 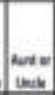 & Instrens & 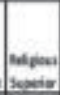 & 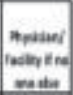 \\
\hline Wating & манив & ing & $x$ & $x$ & $x$ & & & $x$ & $x$ & $x$ & & $x$ & $x$ & $x$ & 1 & 1 & $x$ & & & $x$ \\
\hline Anew & gехин & 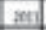 & $x$ & $x$ & $x$ & & $x$ & $x$ & $x$ & $x$ & $x$ & & $x$ & & & & & & & \\
\hline gines & ตละที & $x$ & $x$ & $x$ & $x$ & & $x$ & $x$ & $x$ & $x$ & $x$ & & & & & & & & & \\
\hline Almai & 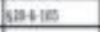 & and & $x$ & $x$ & $x$ & & & $x$ & $x$ & $x$ & & & $x$ & & & & & & & $x$ \\
\hline Gellumit & 5awa & ine & $x$ & & & & & & & & $x$ & & & & & & & & & \\
\hline Sumen & 5115191 & 30 & $x$ & & $x$ & & & $x$ & $x$ & $x$ & $x$ & & & $x$ & & & & & & \\
\hline Smenteal & Masming & net & $x$ & $x$ & $x$ & & & $x$ & $x$ & $x$ & & & & & 1 & & $x$ & & & \\
\hline anmen & Dusecsim & ane & $x$ & $x$ & $x$ & & & $x$ & $x$ & & & & & $x$ & & 1 & & & & \\
\hline Inea & gis:m & anto & $x$ & $x$ & $x$ & & & $x$ & $x$ & $x$ & $x$ & & $x$ & & & & & & & $x$ \\
\hline Eengs. & wast? & anis & $x$ & $x$ & 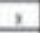 & & & $x$ & $x$ & $x$ & $x$ & & & $x$ & 1 & 1 & $x$ & & & \\
\hline yent & sराया & int & $x$ & & $x$ & & & $x$ & $x$ & $x$ & & & & $x$ & & & & & & \\
\hline $\operatorname{sen}$ & 115 404 & $x_{0}$ & $x$ & $x$ & $x$ & & & $x$ & $x$ & & $x$ & & $x$ & & & & & & & $x$ \\
\hline senit & gascis 400 & $1+8$ & $x$ & $x$ & $x$ & & & $x$ & $\mathrm{x}$ & $\mathrm{I}$ & $x$ & & & $x$ & & & & & & \\
\hline nives & WENH & in: & $x$ & & $x$ & & & $x$ & $x$ & $x$ & & & & & & & & & $x$ & \\
\hline$=$ & $\operatorname{sing}$ & ans & $x$ & $x$ & 3 & & & $x$ & $x$ & $x$ & & & & & & & & & & \\
\hline man & Desalas & & & & & & & & & & & & & & & & & & & \\
\hline mady & guan & 20 & $x$ & $x$ & $x$ & & & $x$ & $x$ & & & & $x$ & & & & & & & \\
\hline envera & 112095 & ines & $x$ & $x$ & $x$ & & & $x$ & $\mathrm{x}$ & $x$ & & & & $x$ & 1 & & & & & \\
\hline thien & vease & ines & $x$ & $x$ & $x$ & & $x$ & $x$ & $x$ & $x$ & $x$ & & $x$ & $x$ & & 1 & $x$ & & & \\
\hline Antent & s seves & xat & $x$ & $x$ & $x$ & 1 & & $x$ & $x$ & $x$ & $x$ & & $x$ & & & & & & & \\
\hline Ansoberem & Geras & & & & & & & & & & & & & & & & & & & \\
\hline Iniven & 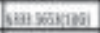 & in & $x$ & & $x$ & & & $x$ & $x$ & $x$ & $x$ & & & & & & & & & \\
\hline Ainendis & beviluds & & & & & & & & & & & & & & & & & & & \\
\hline Anaing & Meatain & ans & $x$ & $x$ & $x$ & & & $x$ & $x$ & $x$ & $x$ & & & & & & & & & \\
\hline Intuse & gasin: & 10 & $x$ & $x$ & $x$ & & & $x$ & $x$ & $x$ & & & $x$ & & & & & & & \\
\hline Strata & pereven & & & & & & & & & & & & & & & & & & & \\
\hline gnat & Wues: & $i$ intis & & & $x$ & 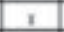 & & & $x$ & $x$ & $x$ & & $x$ & & & & & & & \\
\hline mancenin & geriusin & & & & & & & & & & & & & & & & & & & \\
\hline tanking & Deciente & & & & & & & & & & & & & & & & & & & \\
\hline Wian Neis & 104245 & xis & $x$ & $x$ & $x$ & & $x$ & $x$ & $x$ & $x$ & $x$ & & & & 1 & & & & & \\
\hline Min fren & wass. & $x+4$ & $x$ & $x$ & $x$ & 1 & & $x$ & $x$ & $x$ & $x$ & & & & & & & & & \\
\hline Dinh conilus & mis & $1 \mathrm{ne}$ & $\frac{x}{x}$ & $x$ & $x$ & & & $x$ & $x$ & $x$ & $x$ & & & & & & & & & \\
\hline Sorhaiase & gainu & ingis & $x$ & $x$ & 3 & & & $x$ & $x$ & $x$ & $x$ & & $x$ & $x$ & 1 & & & 1 & & \\
\hline ats & gasm & ine & $x$ & $x$ & $x$ & & & $x$ & $x$ & $x$ & & & $x$ & & & & & & & \\
\hline ayoves & wases & $x^{2}$ & $x$ & $x$ & $x$ & & & $x$ & $x$ & $x$ & & & $x$ & & & & & & & \\
\hline bere & watses & ind & $x$ & $x$ & $x$ & & $x$ & $x$ & 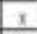 & $x$ & $x$ & & $x$ & & & & & & & \\
\hline mankex, & $\begin{array}{l}\text { waminas } \\
\text { somere }\end{array}$ & mas & $x$ & $x$ & $x$ & & & $x$ & $x$ & $x$ & $x$ & & & $x$ & & & & & & \\
\hline mentions & wereys & & & & & & & & & & & & & & & & & & & \\
\hline Senceriles & $440 x$ & 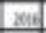 & $x$ & $x$ & $x$ & & & $x$ & $x$ & $x$ & & & $x$ & $x$ & 1 & & & & & \\
\hline Sxhoeret. & Gatuas & $\mathrm{xu}$ & $x$ & $x$ & $x$ & & & $x$ & $x$ & $x$ & $x$ & $x$ & & $x$ & 1 & 1 & $x$ & & & \\
\hline Innaues: & wande & ant & $x$ & $x$ & $x$ & & & $x$ & $x$ & $x$ & $x$ & & $x$ & & & & & & & \\
\hline tan & yisina & ant & $x$ & $x$ & 3 & & & $x$ & $x$ & & & & $x$ & & & & & & $x$ & \\
\hline ma & maxim & ine & $\bar{x}$ & $x$ & $x$ & & & $x$ & $x$ & $x$ & $x$ & & & $x$ & 1 & & & & & \\
\hline vopis & went & xist & $x$ & & $x$ & & & $x$ & $x$ & $x$ & $x$ & & & $x$ & & & & & & \\
\hline Eulagm & susempine & $\mathrm{mis}$ & $x$ & $x$ & $x$ & 1 & & $x$ & $x$ & $x$ & & & & & & & & & & \\
\hline Sed layen & $116 \times 1$ & $\mathrm{at}$ & $x$ & & $x$ & & & $x$ & $x$ & $x$ & $x$ & & & $x$ & & & & & & \\
\hline Earnin & was & 80 & & & 3 & & $x$ & $x$ & $x$ & $x$ & & & $x$ & & & & & & & \\
\hline temey & 15220 & $x a d$ & $x$ & $x$ & $x$ & & & $x$ & $x$ & $x$ & $x$ & & & $x$ & 1 & & & & & \\
\hline
\end{tabular}

